\title{
Acta
Biochimica
Polonica
}

Vol. 51 No. 3/2004

$805-814$

QUARTERLY

\section{Tissue-specific effect of refeeding after short- and long-term caloric restriction on malic enzyme gene expression in rat tissues ${ }^{\star \star}$}

\author{
Ewa Stelmanska, Justyna Korczynska and Julian Swierczynski ${ }^{\bowtie}$
}

Department of Biochemistry, Medical University of Gdańsk, Gdańsk, Poland

Received: 19 November, 2003; revised: 20 February, 2004; accepted: 06 March, 2004

Key words: malic enzyme, caloric restriction, refeeding, white adipose tissue (rat)

\begin{abstract}
Restricting food intake to a level below that consumed voluntarily $(85 \%, 70 \%$ and $50 \%$ of the ad libitum energy intake for 3 or 30 days) and re-feeding ad libitum for 48 $h$ results in an increase of malic enzyme (ME) gene expression in rat white adipose tissue. The increase of ME gene expression was much more pronounced in rats maintained on restricted diet for 30 days than for 3 days. The changes in ME gene expression resembled the changes in the content of SREBP-1 in white adipose tissue. A similar increase of serum insulin concentration was observed in all groups at different degrees of caloric restriction and refed ad libitum for $48 \mathrm{~h}$. Caloric restriction and refeeding caused on increase of ME activity also in brown adipose tissue (BAT) and liver. However, in liver a significant increase of ME activity was found only in rats maintained on the restricted diet for 30 days. No significant changes after caloric restriction and refeeding were found in heart, skeletal muscle, kidney cortex, and brain. These data indicate that the increase of ME gene expression after caloric restriction/refeeding occurs only in lipogenic tissues. Thus, one can conclude that caloric restriction/refeeding increases the enzymatic capacity for fatty acid biosynthesis.
\end{abstract}

All cells in the body require energy to survive and function properly. However, exces- sive calorie intake over long time periods can promote disorders such as cardiovascular dis-

\footnotetext{
* Preliminary report of this work was presented by Ewa Stelmanska at the 39th Meeting of the Polish Biochemical Society, Gdańsk, 16-20 September 2003.

This work was supported by the Medical University of Gdansk (grant St-41) and by the Ministry of Scientific Research and Information Technology (Poland) in years 2003-2004 as a research project (3 P05A 109 25).

${ }^{\otimes}$ Corresponding author: Julian Swierczynski, Department of Biochemistry, Medical University of Gdańsk, ul. Dębinki 1, 80-211 Gdańsk, Poland; fax: (48 58) 349 1465; e-mail: juls@amg.gda.pl

Abbreviations: BAT, brown adipose tissue; ME, malic enzyme [L-malate: NADP $^{+}$oxidoreductase (oxaloacetate-decarboxylating), EC 1.1.1.40]; SREBP-1, sterol regulatory element binding protein; WAT, white adipose tissue.
} 
eases, type-2 diabetes and cancer (Brochu et al., 2000; Lebovitz, 1999; Levi, 1999). Caloric restriction reduces the incidence of age-related cancers, cardiovascular disease and deficits in immune function in rodents (Weindruch et al., 1997). Moreover, dietary restriction is the only known intervention shown to slow aging and to maintain vitality in mammals (Masoro, 1995; Spindler et al., 2003; Weindruch et al., 1988). These effects have been proposed to be achieved by multiple mechanisms. The proposed mechanisms include: (a) a decrease of oxidative stress; (b) a decrease of glycation or glycoxidation; (c) a decrease of body temperature and circulating thyroid hormone concentration associated with hypometabolic state; (d) alterations in gene expression and protein degradation; (e) neuroendocrine changes. However, neither of these mechanisms has been shown to be clearly predominant (Weindruch et al., 2001). Data from Spindler's laboratory indicate that caloric restriction leads to an increase in mRNA level and/or activity of key enzymes of hepatic gluconeogenesis, a decrease in mRNA level and/or activity of key enzymes of hepatic glycolysis, and an increase in mRNA level and/or activity of key enzymes responsible for the disposal of nitrogen derived from muscle protein catabolism (Dhahbi et al., 1999; 2001). Some results suggest that the beneficial effects of caloric restriction include lowering of plasma insulin and IGF-1 concentration, reducing plasma cholesterol and triacylglycerol concentration and elevating of high-density lipoprotein (HDL) level (Anson et al., 2003; Roth et al., 2001; Shimokawa et $a l ., 2003)$. These changes are consistent with the reduction in the expression of some genes of enzymes involved in lipid biosynthesis (Dhahbi et al., 2003; McNeel et al., 2000). Microarray studies indicated that caloric restriction may affect many genes including fatty acid synthase and fatty acid binding protein 2 (Cao et al., 2001), suggesting that caloric restricted animals have a reduced enzy- matic capacity for fatty acid biosynthesis. Caloric restriction during fattening was also shown to reduce intramuscular lipid deposition without modifying muscle fiber characteristics in rabbits (Gondret et al., 2000). This reduction was associated with a decline in the activities of malic enzyme and glucose 6-phosphate dehydrogenase, the enzymes generating NADPH needed for the fatty acid synthesis (Gondret et al., 2000). The questions arise of whether and for how long the beneficial effects of caloric restriction persist, in other words, what happens in caloric restricted rats after refeeding. This is an important medical problem, since, for instance, most obese patients in weight-reduction programs (food restriction) start to regain weight shortly after the end of active therapy (simply after refeeding) (Goodrick \& Foreyt, 1991).

ME is widely distributed in mammalian tissues (Frenkel, 1975). It catalyzes the oxidative decarboxylation of malate to pyruvate and $\mathrm{CO}_{2}$ simultaneously generating $\mathrm{NADPH}$ necessary for: (a) de novo synthesis of long chain fatty acids in lipogenic tissues; (b) cholesterol biosynthesis, and (c) the activity of enzymes involved in the antioxidant system. Since some results suggest that the beneficial effects of caloric restriction include reduced cholesterol and triacylglycerol synthesis as well as a decrease in oxidative stress, it is interesting to find out whether and how caloric restriction/refeeding affects ME gene expression in lipogenic tissues (where ME provides NADPH mainly for fatty acid synthesis) and in nonlipogenic tissues (in which ME provides $\mathrm{NADPH}$ mainly for the enzymes involved in the antioxidant system). The present study was undertaken to determine whether ME gene expression in rat lipogenic tissues (adipose tissues and liver) and non-lipogenic tissues (heart, kidney cortex, brain and skeletal muscle) is affected by refeeding after short ( 3 days) and long (30 days) period of caloric restriction. 


\section{MATERIALS AND METHODS}

Animals. Ten weeks old male Wistar rats weighing approximately $240 \mathrm{~g}$ at the start of the investigation were housed in wire-mesh cages at $22^{\circ} \mathrm{C}$ under a light: dark $(12: 12 \mathrm{~h})$ cycle with lights on at 7:00 a.m. The rats were divided randomly into four groups. Group A (control) was allowed free access to food and tap water. The remaining groups of animals obtained every morning 85\% (group B), 70\% (group C) and 50\% (group D) of the total amount of food consumed by the control group. The average daily food intake by group A was measured by the difference in weight between the amount of food provided and the amount remaining after one day. After 3 days (short-term caloric restriction) or one month (long-term caloric restriction) of such treatment, each group was allowed free access to food for $48 \mathrm{~h}$ and then the rats were killed (between 8:00 and 10:00 a.m.). The commercial diet used in all groups was the same as described in (Kochan et al., 1997). Tissues (white adipose tissue, brown adipose tissue, liver, heart, skeletal muscle, brain and kidney cortex) were collected and rapidly frozen in liquid nitrogen. The tissues were stored at $-80^{\circ} \mathrm{C}$ until analysis. Blood was collected after cutting of neck artery. All animal procedures were conducted in agreement with our institutional guidelines for the care and use of laboratory animals.

Probes design and labelling. ME mRNA level was detected using a 32-mer oligonucleotide (5'CTC ACT CGC CTG TGC CGC AGC CCA ATA TAC AA $3^{\prime}$ ) complementary to rat ME (Karbowska et al., 1999).

31-mer antisense oligonucleotide (5'CGC CTG CTG CCT TCC TTG GAT GTG GTA GCC G3') was used as a probe for 18S rRNA (Trayhurn et al., 1995). The oligonucleotides were synthesized commercially (GENSET SA, Paris, France) with a single digoxigenin ligand at the $3^{\prime}$ end.

Isolation of RNA and Northern blot analysis. Total cellular RNA was extracted from frozen tissue (approx. $1 \mathrm{~g}$ of tissue was used) by the guanidinium isothiocyanate/phenol/chloroform method (Chomczynski \& Sacchi, 1987) and finally dissolved in dimethyl pyrocarbonate-treated water. The RNA concentration was determined from the absorbance at $260 \mathrm{~nm}$ and all samples had the $260 / 280 \mathrm{~nm}$ absorbance ratio of about 2.0. RNA samples (10 $\mu \mathrm{g}$ per lane) were fractionated by horizontal gel electrophoresis on $1 \%$ agarose gels containing $0.41 \mathrm{M}$ formaldehyde. After electrophoretic fractionation, RNA was transferred overnight to a positively charged nylon membrane (Roche, Mannheim, Germany) by capillary blotting and fixed with UV light. Pre-hybridization and hybridization were performed as described (Trayhurn et al., 1995).

Signals were scanned and quantified using the Sigma Scan software program (Jandel Scientific Co.). The values of the ME mRNA signal were normalized against the $18 \mathrm{~S}$ rRNA signal. The results expressed in arbitrary units are presented as means \pm standard deviation (S.D.) of samples from 10 rats.

Western blot analysis of ME. Polyclonal rabbit anti-ME antibody was prepared as described recently (Korczynska et al., 2000). White adipose tissue cytosol was mixed with sample buffer, boiled ( $5 \mathrm{~min}$ at $100^{\circ} \mathrm{C}$ ), separated by SDS/PAGE and electroblotted to Immobilon $\mathrm{P}$ membrane (Sigma Chemical Co., St Louis, MO, U.S.A.). The membrane was blocked by incubation in blocking buffer, incubated with polyclonal anti-ME antibody, washed and incubated with alkaline phosphatase-conjugated secondary antibody. Signal was revealed by membrane incubation in a buffer containing: $0.1 \mathrm{M}$ Tris, $0.1 \mathrm{M} \mathrm{NaCl}$, $\mathrm{pH}$ 9.5, and 0.4\% CDP-Star (disodium 2-chloro-5-[4-methoxyspiro\{1,2-dioxetane-3,2'(5'-chloro)tricyclodecan\}-4-yl)-1-phenyl phosphate (Roche, Mannheim, Germany).

\section{Western blot analysis of SREBP-1.} Frozen rat epididymal white adipose tissue (about $200 \mathrm{mg}$ ) was homogenized in $1 \mathrm{ml}$ of $7 \%$ SDS. Aliquots of the homogenates con- 
taining $30 \mu \mathrm{g}$ protein were mixed with sample buffer, boiled $\left(1 \mathrm{~min}\right.$ at $\left.100^{\circ} \mathrm{C}\right)$ and centrifuged for $10 \mathrm{~min}$ at $3000 \times \mathbf{g}$ as described (Vecchini et al., 2003). The relative abundance of precursor and mature SREBP-1 was evaluated by Western blot procedure as described above. Polyclonal rabbit antibody against SREBP-1 was obtained from Santa Cruz Biotechnology. SDS/PAGE gels were calibrated with molecular mass markers (MBI Fermentas, Lithuania).

Enzyme activity assay. Frozen $1 \mathrm{~g}$ samples of tissues were placed in $8 \mathrm{ml}$ ice-cold 20 $\mathrm{mM}$ Tris/Cl buffer (pH 7.8) containing $0.2 \%$ Triton X-100. The tissues were minced finely with scissors, homogenized manually with a Teflon-pestle homogenizer, and centrifuged at $30000 \times \boldsymbol{g}$ for $20 \mathrm{~min}$. The resulting supernatant was decanted, and the pellet resuspended in $5 \mathrm{ml}$ isolation medium, rehomogenized, and centrifuged as above. The resulting supernatant was combined with that from the first centrifugation step and used for enzyme assay. ME was assayed as described previously (Zelewski \& Swierczynski, 1990). It should be noted that one month storage at $-80^{\circ} \mathrm{C}$ did not affect the enzyme activity.

Data analysis. Results are expressed as means \pm S.D. of samples from 10 rats. The statistical significance of differences between groups was assessed by one-way analysis of variance (ANOVA) followed by Student's $t$-test using the Systat software (Systat Inc.). Differences between groups were considered as significant when $P<0.05$.

\section{RESULTS}

The rats given restricted diets for one month and then refed ad libitum for $48 \mathrm{~h}$ gained significantly less weight than the control rats fed ad libitum (not shown). The weight of epididymal, perirenal and inguinal adipose tissues in those rats decreased with the decreasing food intake by the animals (not shown). No significant changes in body and white adipose tissue weight in the rats maintained on short-term caloric restriction diet were found (not shown). The average, daily food intake by the control rats was $30 \pm$ $3 \mathrm{~g}$ throughout the period of experiment. During the first day of re-feeding the daily food intake by the rats on restricted diet (in all the groups) was $45 \pm 4 \mathrm{~g}$ and then fell to $30 \pm 3 \mathrm{~g}$ (irrespectively of the group tested) on the second day of re-feeding.

The effect of refeeding for $48 \mathrm{~h}$ on ME activity in epididymal white adipose tissue of rats maintained on short-term (3 days) and long-term (30 days) caloric restriction is presented in Fig. 1 (bottom panel). In the rats given restricted diets $(85 \%, 70 \%$ and $50 \%$ of $a d$ libitum energy intake) both for 3 and 30 days and refed, the ME activity in WAT increased significantly as compared to the control animals. However, the increase of ME activity was much higher in rats maintained on caloric restriction for a long time. The ME activity reached the highest level in rats provided with the daily food allotment limited to $50 \%$ of that eaten by the ad libitum fed animals. The data presented in Fig. 1 (bottom panel) also show statistically significant differences between ME activity in rats maintained on the same restricted diet for short and long time. The pattern of the ME activity changes resembles that of the changes in ME protein level determined by Western blot analysis (Fig. 1, top panel). The effect of feeding ad libitum for $48 \mathrm{~h}$ on the level of ME mRNA in epididymal white adipose tissue of rats maintained on short- and long-term caloric restriction is presented in Fig. 2. Figures 2A (3 days) and 2B (30 days) show a representative Northern blot analysis. These results indicate that caloric restriction induces a substantial increase of ME mRNA level in white adipose tissue (Figs. 2A, B, C). The data also show statistically significant differences between ME mRNA levels in rats maintained on the same restricted diet for short and long time. The pattern of ME activity (Fig. 1) and protein level (deter- 
mined by Western blot analysis) (Fig. 1) changes resemble that of the changes in ME mRNA abundance (Fig. 2). To gain more in- short and long time was found (Fig. 3). The caloric restriction and refeeding did not affect significantly the serum glucose concen-
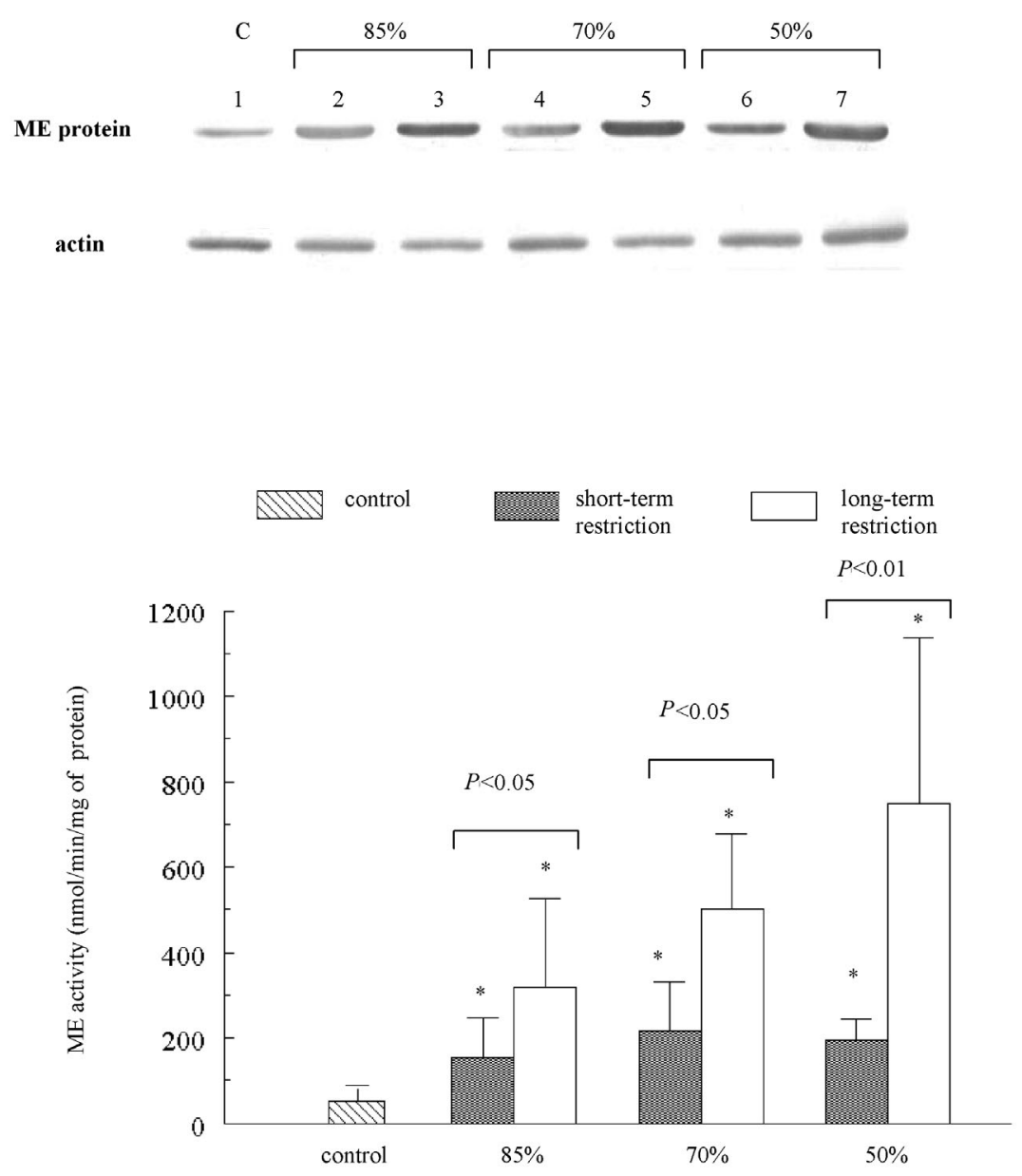

Figure 1. Western blot analysis of ME protein levels (top panel) and ME activity (bottom panel) in epididymal white adipose tissue of rats treated with restricted diet and refed.

Lane 1 represents control (rats fed ad libitum). Lanes 2 and 3, rats on restricted diet, 85\% of the ad libitum energy intake, for 3 and 30 days. Lanes 4 and 5, rats on restricted diet, $70 \%$ of the ad libitum energy intake, for 3 and 30 days. Lanes 6 and 7, rats on restricted diet, $50 \%$ of the ad libitum energy intake, for 3 and 30 days. The actin was used as a standard (top panel). Data represent means \pm S.D. ${ }^{*} P<0.001$, significant differences in ME activity between the control and treated animals (bottom panel).

sight into the mechanism of the increase of ME gene expression in WAT induced by caloric restriction and refeeding, serum insulin (a hormone know to induce ME gene expression) and glucose concentrations were examined. A similar increase in serum insulin concentration was observed both in rats maintained on short- and long-term caloric restriction and refed. No significant difference between serum insulin concentration in rats maintained on the same restricted diet for tration (not shown). Because SREBP-1 plays an important role in the regulation of the lipogenic enzyme gene expression, altered regulation of this transcription factor in caloric restriction could be involved in the regulation of ME gene expression (Osborne, 2000). Immunoblotting of white adipose tissue extracts revealed a significant increase in both precursor (microsomal) and mature (nuclear) forms of SREBP-1 in caloric restriction rats as compared to the control (Fig. 4). The re- 


\section{A}

ME mRNA

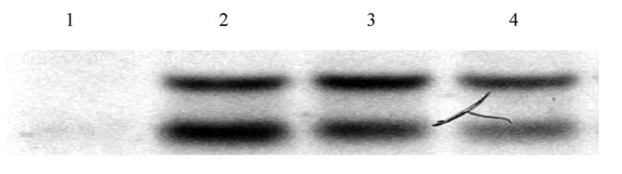

18 S rRNA
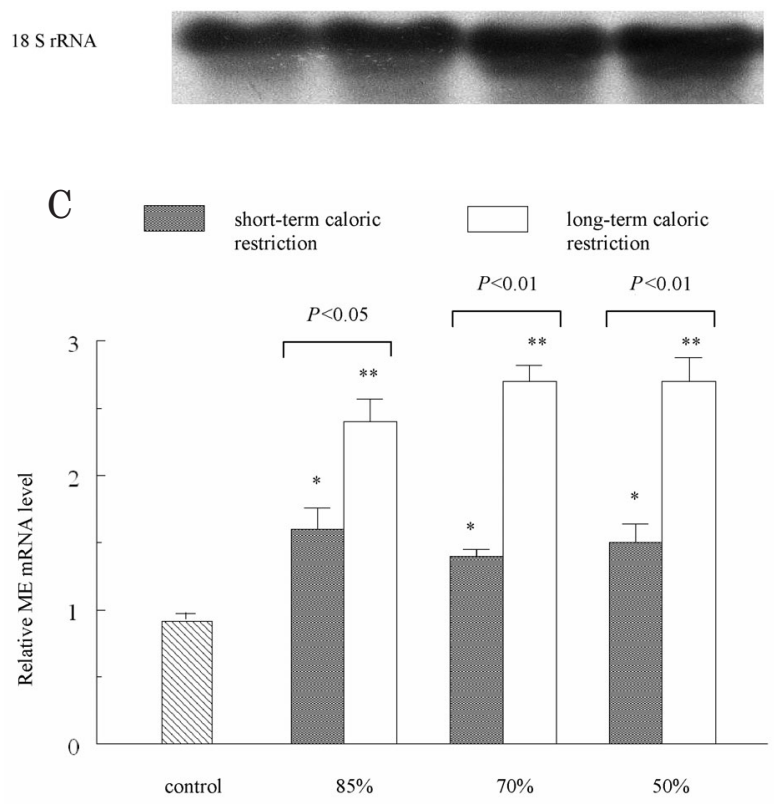

sults presented in Fig. 4 indicate that short-term (Fig. 4A) and long-term (Fig. 4B) caloric restriction and refeeding cause an increase of both the precursor and the mature form of SREBP-1. Moreover, the increase of SREBP-1 abundance was higher in rats maintained on caloric restriction for 30 days than in animals treated in this way for 3 days. In general, the nuclear content of SREBP-1 reflects the amount of microsomal SREBP-1 (Fig. 4). The changes in the content of SREBP-1 are similar to the changes in ME gene expression (ME activity, protein abundance and mRNA level; Figs. 1 and 2) in white adipose tissue. To gain more information about the tissue specificity of the caloric restriction/refeeding-related changes in ME activity we compared the enzyme activity in: WAT, BAT, liver, heart, skeletal muscle, brain, and kidney cortex obtained from rats maintained on $50 \%$ caloric restriction for 3 and 30 days and refed for $48 \mathrm{~h}$ before killing. The results presented in Table 1 indicate that liver (in contrast to WAT) displays no signifi-

\section{B}

ME mRNA

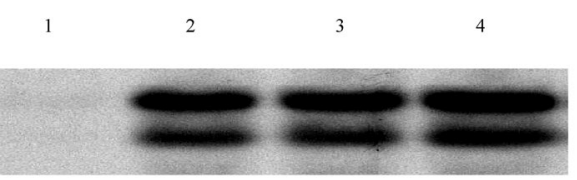

18 S rRNA

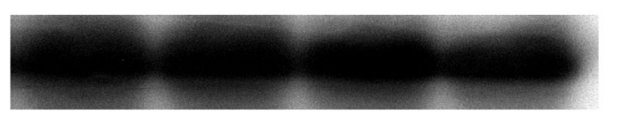

Figure 2. Northern blot analysis of ME mRNA in epididymal white adipose tissue of rats treated with short-term caloric restriction (A) and long-term caloric restriction (B) and refed. Relative ME mRNA level (C).

Lane 1 represents control (rats fed ad libitum); lane 2 , rats fed $85 \%$; lane 3 , rats fed $70 \%$; lane 4 , rats fed $50 \%$ of the ad libitum energy intake. 18S rRNA was used as a standard (A, B). Blots (from 5 rats per group) were scanned and quantified by the Sigma Scan software program. Data represent means \pm S.D. Statistically significant differences in ME mRNA level between the control and treated animals are marked $\left({ }^{*} P<0.05\right.$ and $\left.{ }^{* *} P<0.001\right)(\mathrm{C})$.

cant changes in ME activity after short caloric restriction. About two-fold higher liver ME activity was found after long-term caloric restriction. BAT from the caloric restriction/ refed rats, both after short- and long-term caloric restriction, had about 5-fold higher ME activity than that from control animals. The pattern of changes in the liver and BAT ME activity resembled those of the changes in the abundance of ME protein and ME mRNA (not shown). No differences of the enzyme activity were observed in the heart, skeletal muscle, brain and kidney cortex obtained from animals treated by caloric restriction. The results presented in Table 1 indicate that caloric restriction/refeeding conditions affect $\mathrm{ME}$ gene expression only in lipogenic tissues.

\section{DISCUSSION}

Several studies have been reported examining the effect of caloric restriction on the activity and gene expression of enzymes in- 


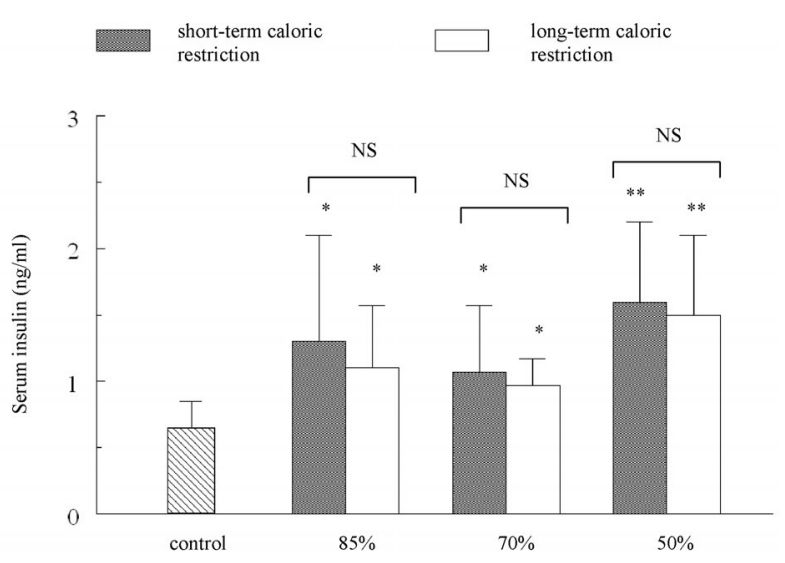

Figure 3. Serum insulin concentration in control animals and in rats maintained on different diets.

Data represent means \pm SD. Statistically significant differences in serum insulin concentration between the control and treated rats are made $\left({ }^{*} P<0.05\right.$ and $\left.{ }^{* *} P<0.001\right)$. NS, not significant.

volved in lipid metabolism (Cao et al., 2001; Gondret et al., 2000; Goodrick \& Foreyt, 1991; Spindler et al., 2003). However, there is little information published so far concerning the lipogenic enzymes gene expression in response to refeeding of caloric restriction rats. Recently we have found that gene expression of the key lipogenic enzyme - fatty acid synthase - increased significantly in white adipose tissue after refeeding of rats subjected to food restriction (Korczynska et al., 2003). ME is another enzyme belonging to the lipogenic enzymes family. The present study demonstrated that the ME gene expression (ME activity, protein abundance and mRNA level) in epididymal white adipose tissue increases markedly in response to caloric restriction for both short and long time and subsequent refeeding ad libitum for $48 \mathrm{~h}$. The differences between the changes of serum insulin concentration and WAT ME gene expression in our experimental animals suggest that insulin could only be partially responsible for the changes in ME gene expression. The most important finding in this report is that the increase in SREBP-1 level is associated with the up-regulation of ME gene expression in calo-
A short-term caloric restriction

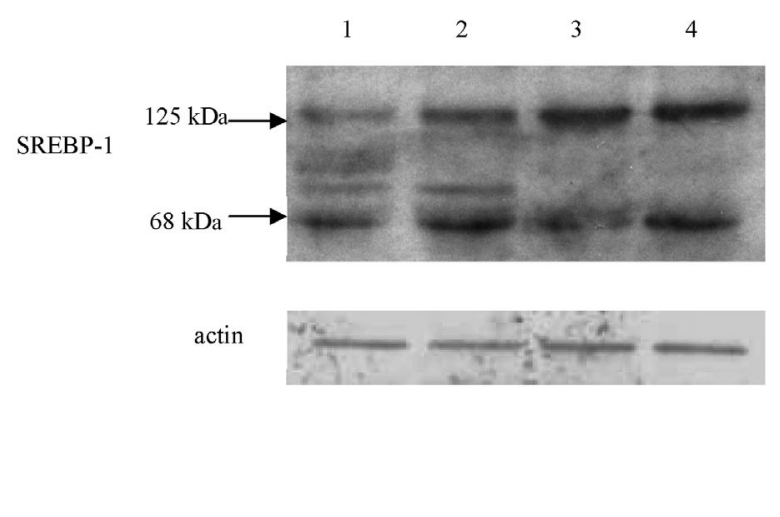

B long-term caloric restriction

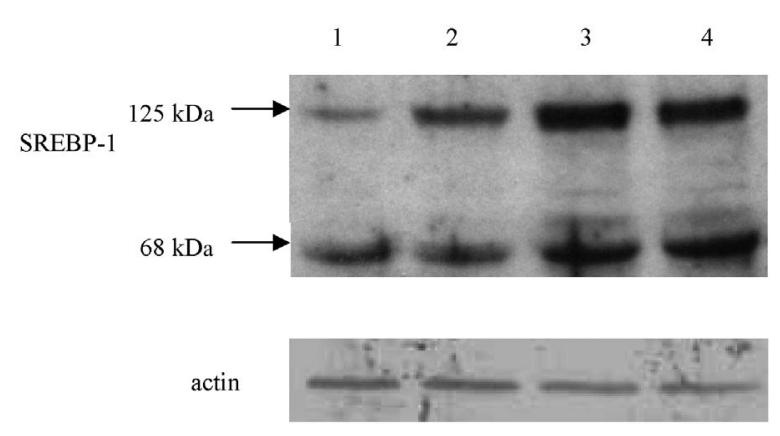

Figure 4. Western blot analysis of SREBP-1 levels in epididymal white adipose tissue of rats treated with short-term caloric restriction (A) and long-term caloric restriction (B) and refed.

Lane 1 represents control (rats fed ad libitum); lane 2, rats fed $85 \%$; lane 3, rats fed $70 \%$; lane 4 , rats fed $50 \%$ of the ad libitum energy intake. The actin was used as a standard.

ric restriction/refed rats. The coordinated up-regulation of ME and SREBP-1 suggests that SREBP-1 plays a key role in the regulation of ME gene expression in WAT from rats maintained on caloric restriction for short and long time and refed. One may conclude that as a consequence of the up-regulation of SREBP-1 and its target genes, a higher activity of $\mathrm{ME}$ is observed in white adipose tissue of caloric restriction rats as compared to control. The data presented in this paper also indicate that white and brown adipose tissues are the most sensitive tissues to caloric restriction/refeeding as far as changes in $\mathrm{ME}$ gene expression are concerned. In both these 
tissues the increase in $\mathrm{ME}$ gene expression was observed after short- and long-term caloric restriction/refeeding. In liver these changes were found only after long-term caloric restriction. The question of why the increase in ME gene expression in adipose tissue (both in WAT and BAT) was much higher check this we analysed the cytosolic ME mRNA level in the heart of control rats and those maintained on caloric restriction. No differences were found. Thus it is very likely that in heart, skeletal muscle, kidney cortex and brain $\mathrm{ME}$ gene expression is not regulated by caloric restriction. Considering that

Tabela 1. Malic enzyme activity in tissues of rats maintained on $50 \%$ caloric restriction/refed

\begin{tabular}{llll}
\hline Tissues & Control & Short-term caloric restriction & Long-term caloric restriction \\
\hline WAT(\#) & $51.6 \pm 34$ & $194.7 \pm 49^{* *}$ & $748 \pm 394^{* *}$ \\
BAT(\#\#) & $118 \pm 34$ & $676 \pm 50^{* *}$ & $522 \pm 59^{* *}$ \\
Liver & $17 \pm 5$ & $22 \pm 2$ & $45 \pm 10^{*}$ \\
Brain & $47.2 \pm 4.9$ & $47 \pm 8$ & $53.6 \pm 4.3$ \\
Heart & $70 \pm 6.7$ & $79 \pm 8$ & $59 \pm 7.5$ \\
Skeletal muscle & $22 \pm 1.3$ & $20 \pm 2$ & $20.1 \pm 2.6$ \\
Kidney cortex & $20.7 \pm 3.4$ & $22 \pm 4$ & $20.7 \pm 5.5$ \\
\hline
\end{tabular}

Malic enzyme activity expressed as $\mathrm{nmol} / \mathrm{min} / \mathrm{mg}$ of protein. Data represent mean \pm S.D. For comparison with control: ${ }^{*} P<0.01 ;{ }^{* *} P<0.001 ;{ }^{\#}$ Epididymal white adipose tissue ${ }^{\# \#}$ Intrascapular brown adipose tissue.

than in the liver remains unanswered. It is well documented that in the liver, WAT and BAT more than $90 \%$ of total ME activity is present in the cytosol (Brdiczka \& Pette, 1971). Thus it is unlikely that the intracellular distribution of ME could contribute to these differences. One can only speculate that adipose tissue is much more sensitive than the liver to an alteration in the hormonal milieu, which takes place during caloric restriction/refeeding. The lack of caloric restriction/refeeding effect on ME gene expression in heart, skeletal muscle, kidney cortex and brain suggests that the enzyme is not regulated in a coordinate fashion. However, these tissues exhibit a considerable activity of ME in the mitochondria (Brdiczka \& Pette, 1971). Considering that only the cytosolic enzyme is regulated in different metabolic conditions (Frenkel, 1975), one cannot exclude that cytosolic ME activity in these tissues is slightly enhanced, but is masked by the mitochondrial activity in total tissue extracts. To white and brown adipose tissue and liver belong to the lipogenic tissues, one can conclude that changes in ME gene expression in response to caloric restriction/refeeding are characteristic for lipogenic tissues only.

Taken together, these results suggest that the enzymatic capacity for lipogenesis of the adipose tissue (both WAT and BAT) and liver is enhanced after refeeding of long-term caloric restriction rats. This may be relevant to obese humans who try to lose weight by temporary limited food ingestion.

We are indebted to Professor Mariusz M. Zydowo for critique and discussion of the manuscript, and Mrs Elzbieta Goyke for technical assistance.

\section{R E F E R E N C E S}

Anson RM, Guo Z, de Cabo R, Iyun T, Rios M, Hagepanos A, Ingram DK, Lane MA, 
Mattson MP. (2003) Intermittent fasting dissociates beneficial effects of dietary restriction on glucose metabolism and neuronal resistance to injury from calorie intake. Proc Natl Acad Sci USA.; 100: 6216-20.

Brdiczka D, Pette D. (1971) Intra- and extramitochondrial isozymes of (NADP) malate dehydrogenase. Eur J Biochem.; 19: 546-51.

Brochu M, Poehlman ET, Ades PA. (2000) Obesity, body fat distribution, and coronary artery disease. J Cardiopulm Rehabil.; 20: 96-108.

Cao SX, Dhahbi JM, Mote PL, Spindler SR. (2001) Genomic profiling of short- and long-term caloric restriction effects in the liver of aging mice. Proc Natl Acad Sci USA.; 98: 10630-5.

Chomczynski P, Sacchi N. (1987) Single-step method of RNA isolation by acid guanidinium thiocyanate-phenol-chloroform extraction. Anal Biochem.; 162: 156-9.

Dhahbi JM, Mote PL, Wingo J, Tillman JB, Walford RL, Spindler SR. (1999) Calories and aging alter gene expression for gluconeogenic, glycolytic, and nitrogen-metabolizing enzymes. Am J Physiol Endocrinol Metab.; 277: E352-60.

Dhahbi JM, Mote PL, Wingo J, Rowley BC, Cao SX, Walford RL, Spindler SR. (2001) Caloric restriction alters the feeding response of key metabolic enzymes genes. Mech Ageing Dev; 122: $1033-48$.

Dhahbi JM, Mote PL, Cao SX, Spindler SR. (2003) Hepatic gene expression profiling of streptozotocin-induced diabetes. Diabetes Technol Ther., 5: 411-20.

Frenkel R. (1975) Regulation and physiological functions of malic enzymes. Curr Top Cell Regul.; 9: 157-81.

Gondret F, Lebas F, Bonneau M. (2000) Restricted feed intake during fattening reduces intramuscular lipid deposition without modifying muscle fiber characteristics in rabbits. J Nutr:; 130: 228-33.
Goodrick GK, Foreyt JP. (1991) Why treatments for obesity don't last. J Am Diet Assoc.; 91: $1243-7$.

Karbowska J, Kochan Z, Zelewski L, Swierczynski J. (1999) Tissue specific effect of clofibrate on rat lipogenic enzyme gene expression. Eur J Pharmacol.; 370: 329-36.

Kochan Z, Karbowska J, Swierczynski J. (1997) Unusual increase of lipogenesis in rat white adipose tissue after multiple cycles of starvation-refeeding. Metabolism.; 46: 10-7.

Korczynska J, Stelmanska E, Nieweglowski T, Szolkiewicz M, Rutkowski B, Swierczynski J. (2000) Effect of clofibrate on plasma lipid concentration and malic enzyme gene expression in rats with experimental chronic renal failure. Pol J Pharmacol.; 52: 291-7.

Korczynska J, Stelmanska E, Swierczynski J. (2003) Differential effect of long term food restriction on fatty acid synthase and leptin genes expression in rat white adipose tissue. Horm Metab Res.; 35: 593-7.

Lebovitz HE. (1999) Type 2 diabetes: an overview. Clin Chem.; 45: 1339-45.

Levi F. (1999) Cancer prevention: epidemiology and perpectives. Eur J Cancer.; 35: 1912-24.

Masoro EJ. (1995) Dietary restriction. Exp Gerontol.; 30: 291-8.

McNeel RL, Mersmann HJ. (2000) Nutritional deprivation reduces the transcripts for transcription factors and adipocyte-characteristic proteins in porcine adipocytes. $J$ Nutr Biochem.; 11: 139-46.

Osborne TF. (2000) Sterol regulatory element-binding proteins (SREBPs): key regulators of nutritional homeostasis and insulin action. J Biol Chem.; 275: 32379-82.

Roth GS, Ingram DK, Lane MA. (2001) Caloric restriction in primates and relevance to humans. Ann N Y Acad Sci.; 928: 305-15.

Shimokawa I, Higami Y, Tsuchiya T, Otani H, Komatsu T, Chiba T, Yamaza H. (2003) Life span extension by reduction of the growth hormone-insulin-like growth-1 axis: relation to caloric restriction. FASEB J.; 17: 1108-9. 
Spindler SR. (2003) Caloric restriction, longevity and the search for authentic anti-aging drugs. In: Kinney B, Carraway J, eds, Quality Medical Publishing, Inc., St Louis.

Trayhurn P, Duncan JS, Rayner DV. (1995) Acute cold-induced suppression of $o b$ (obese) gene expression in white adipose tissue of mice: mediation by the sympathetic system. Biochem J.; 311: 729-33.

Vecchini A, Ceccarelli V, Orvietani P, Caligiana P, Susta F, Binaglia L, Nocentini G, Riccardi C, Di Nardo P. (2003) Enhanced expression of lipogenic enzymes in an animal model of sedentariness. J Lipid Res.; 44: 698-704.

Weindruch R, Walford RL. (1988) The Retardation of Aging and Disease by Dietary Restric- tion. Charles C Thomas Publisher, Springfield, IL.

Weindruch R, Sohal RS. (1997) Seminars in medicine of the Beth Israel Deaconess Medical Center. Caloric intake and aging. $N$ Engl J Med.; 337: 986-94.

Weindruch R, Kayo T, Lee Ch-K, Prolla TA. (2001) Microarray profilling of gene expression in aging and its alteration by caloric restriction in mice. $J$ Nutr.; 131: 918S-23S.

Zelewski M, Swierczynski J. (1990) Comparative studies on lipogenic enzyme activities in brown adipose tissue and liver of rat during starvation-refeeding transition and cold exposure. Comp Biochem Physiol.; 97B: 59-63. 